\title{
GPS-controlled tide gauges in Indonesia - a German contribution to Indonesia's Tsunami Early Warning System
}

\author{
T. Schöne ${ }^{1}$, J. Illigner ${ }^{1}$, P. Manurung ${ }^{2}$, C. Subarya ${ }^{2}$, Khafid $^{2}$, C. Zech ${ }^{1}$, and R. Galas ${ }^{3}$ \\ ${ }^{1}$ Deutsches GeoForschungsZentrum GFZ, Potsdam, Germany \\ ${ }^{2}$ Badan Koordinasi Survei dan Pemetaan Nasional (BAKOSURTANAL), Cibinong, Indonesia \\ ${ }^{3}$ Institut für Geodäsie und Geoinformationstechnik, TU Berlin, Berlin, Germany
}

Received: 13 August 2010 - Revised: 1 February 2011 - Accepted: 1 February 2011 - Published: 9 March 2011

\begin{abstract}
Coastal tide gauges do not only play a central role in the study of climate-related sea level changes but also in tsunami warning systems. Over the past five years, ten GPScontrolled tide gauge systems have been installed by the German Research Centre for Geosciences (GFZ) in Indonesia to assist the development of the Indonesian Tsunami Early Warning System (InaTEWS). These stations are mainly installed at the Indonesian coastline facing the Indian Ocean. The tide gauge systems deliver information about the instantaneous sea level, vertical control information through GPS, and meteorological observations. A tidal analysis at the station's computer allows the detection of rapid changes in the local sea level ("sea level events"/SLE), thus indicating, for example, the arrival time of tsunamis. The technical implementation, communication issues, the operation and the sea level event detection algorithm, and some results from recent earthquakes and tsunamis are described in this paper.
\end{abstract}

\section{Introduction}

The disastrous tsunami in Banda Aceh (Northern Sumatra) on 26 December 2004, and the severe earthquake close to Nias Island (Northern Sumatra) on 28 March 2005, caused unexpected catastrophes in Indonesia and other countries around the Indian Ocean. Although several sensor systems (seismographs, tide gauges and GPS stations) had already been in operation in Indonesia, no tsunami warning system was in operation at that time. As a consequence, Indonesia, with the help of international partner organizations started to design and implement a Tsunami Early Warning System

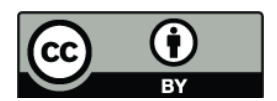

Correspondence to: T. Schöne (tschoene@gfz-potsdam.de)
(InaTEWS). Part of this system is a network of shore-based tide gauges which continuously measure the local sea level and provide arrival times and amplitudes of tsunamis in near real-time. Within the German Indonesian Tsunami Early Warning System (GITEWS) project (Rudloff et al., 2009) and as a contribution to InaTEWS, Germany provided 10 GPS-controlled tide gauges installed at locations facing the Indian Ocean.

For many years, the sea level in coastal areas has been observed by tidal recordings to understand the phenomena of tides, storm surges and tsunamis. Since the 19th century, mechanical tidal recorders have been installed and operated successfully; also a few recordings of tsunamis have since then been made. Today, the usage of automatic digital tide gauge systems has improved the availability of real time data and the reliability and accuracy of tidal data recordings through higher sampling rates, modern data loggers and satellite data transmission. A network of tide gauges in remote areas close to seismically active regions can thus provide important information for the early detection of tsunamis, the estimation of tsunami arrival times and support the run-up height estimation at the coast. After the Banda Aceh tsunami in 2004, the number of tide gauges in Indonesia increased significantly from 25 digital and 35 analogue stations in 2004 (Manurung, 2007) to almost 100 stations with near realtime reporting capabilities in 2010. While the Indonesian Coordinating Agency for Surveys and Mapping (BAKOSURTANAL) has installed almost 80 stations, 10 stations have been donated by the Intergovernmental Oceanographic Commission (IOC) and the USA, and 10 additional GPScontrolled tide gauges by Germany (Fig. 1). This paper focuses on the GITEWS tide gauge stations installed on sites at the islands of Sumatra, Java, Sumba, and Rote facing the Indian Ocean. The station design and the operation will be described in detail. 


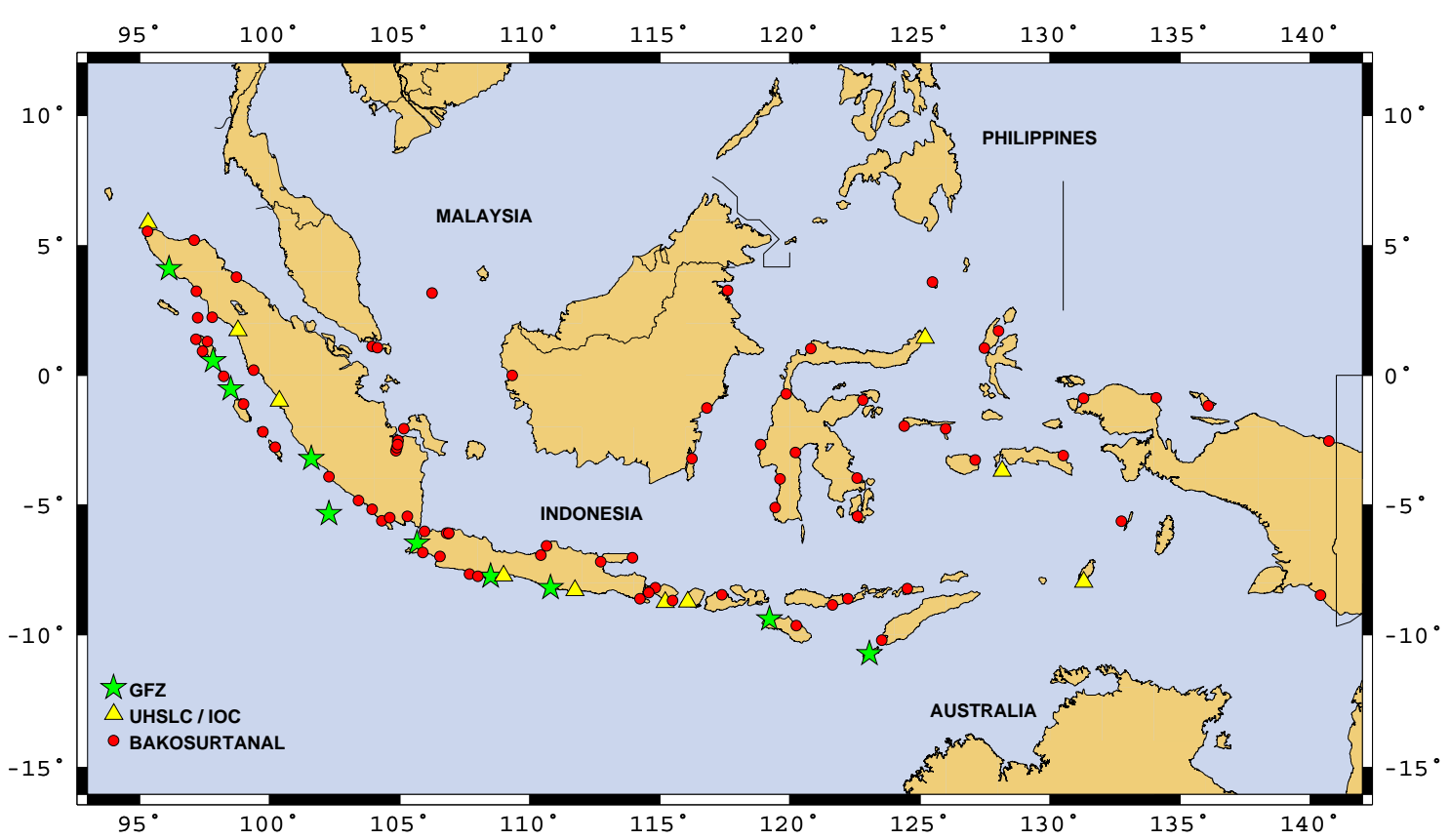

Fig. 1. Distribution of tide gauges in Indonesia with real-time or near real-time reporting. Red dots are stations installed by BAKOSURTANAL, green stars are stations installed by GFZ through GITEWS, and yellow triangles are stations installed by UHSLC (USA) for NOAA and IOC.

\section{GPS-controlled tide gauges}

All GITEWS tide gauge installations follow the best practice of the Global Sea Level Observing System (GLOSS) (e.g., Merrifield et al., 2009; UNESCO, 2006) and have the main purpose to provide near real-time information for tsunami warnings and the monitoring of long-term sea level changes. The stations combine continuous sea level monitoring with an automated alert in case of a rapid sea level change as well as the monitoring of movements of the tide gauge station with GPS. The tide gauges installed by BAKOSURTANAL as well as by IOC and USA are for the monitoring and realtime transmission of sea level data only.

\subsection{Technical realization}

The tide gauge stations (Fig. 2a and $2 \mathrm{~b}$ ) are designed as independent systems to be installed in remote areas with little infrastructure (e.g., no reliable or existing local power supply, no available communication network). The whole system is rugged and equipped with intelligent software, hardware and power management system. Redundant sensors guarantee continuous operation with minimal human interaction. The stations have two main components: the tide gauge system with different sensors to measure the water level, and the land station with the main computer, power supply, additional sensors (e.g., GPS and meteorological sensors), and the communication system. Both components are usually placed in one tide gauge hut, but can be separated from each

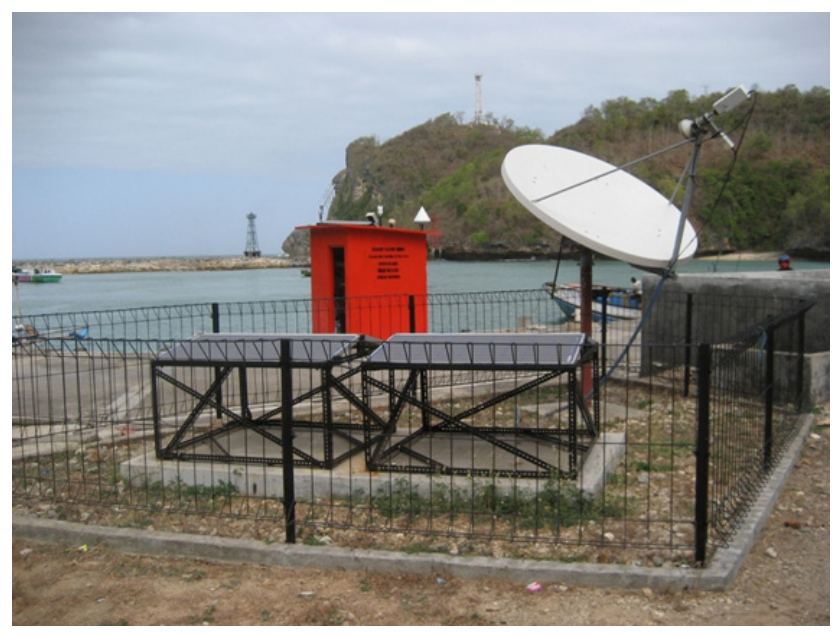

Fig. 2a. An example of a GPS-controlled tide gauge station (Sadeng, Java/Indonesia) of the GITEWS project in support of the InaTEWS system of Indonesia. The station is equipped with radar, float and pressure gauges. The GPS antenna is mounted on the top of the tide gauge hut. In addition, the meteorological sensor is visible as well as some antennas for data transmission.

other and connected by HF communication in case of local requirements (e.g., no sufficient space for solar panels at the pier, no reliable GPS pillar monumentation is possible). At seismological interesting sites, an additional strong-motion accelerometer is installed. 


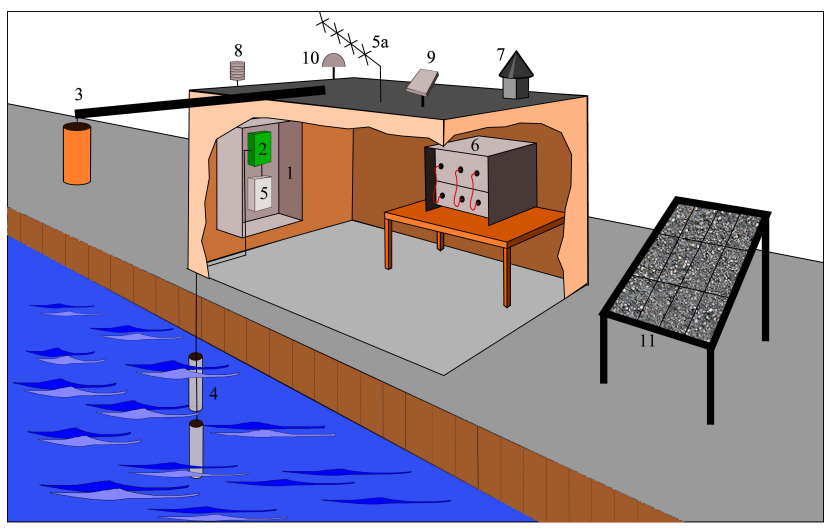

Fig. 2b. Schematic sketch of a typical tide gauge station. Legend: Tide gauge compartment (1) with tide gauge data logger (2), radar gauge (3) and pressure gauges (4). International tide gauge users are served by the GTS communication (5) with a YAGI antenna (5a). The rack (6) hosts the computer, power module, GPS receiver with a choke ring antenna (7) mounted on top of the tide gauge hut. Additionally, a compact meteorological sensor (8) provides basic environmental information. The main communication line is the BGAN system (9) with a PASTI (10) as backup. An array of solar cells (11) provides power for uninterrupted operation.

For redundancy, the tide gauge system usually consists of three water level sensors, except at a few sites with difficult local conditions, where only a single sensor is installed. The installed types of sensors are radar gauges, pressure gauges and shaft encoders. First, the low-maintenance radar gauge (OTT Kalesto) measures the distance between its reference point and the water surface with an averaging of the single high-rate measurements over a few seconds. The radar gauge is usually mounted on top of the tide gauge hut with an U-profile steel girder. A secondary pressure gauge (OTT ODS4-K) measures the static pressure of the water and is mounted in the water with a metal construction. The pressure probe is rated to $40 \mathrm{dBar}$ and is, therefore, even operable during a tsunami. Additionally, a shaft encoder (OTT OWK16) registers changes in the water level with a float in a stilling well. Shaft encoders have been operated successfully during the last 20 years in Indonesia and will continue to be used. At each station, a radar gauge and a pressure gauge is installed as the standard instrumentation with either a second pressure gauge or a shaft encoder as the third sensor. All sensors are connected to a data logger (OTT LogoSens2) which provides data logging, storage and control functions for the sensors as well as the data transmission through the public meteorological satellites and hence on to the Global Telecommunication System (GTS) of the World Meteorological Organization (EUMETSAT, 2009). The internal sampling rate of the tide gauge system is $20 \mathrm{~s}$ for the pressure gauge and shaft encoder, and a varying sampling rate for the Kalesto radar gauge (from $17 \mathrm{~s}$ to $1 \mathrm{~min}$, depending on the sensor's internal averaging algorithm). The data logger is connected to the sta- tion's PC where all data is stored and transmitted on a daily basis to the data processing center at BAKOSURTANAL (Indonesia).

As the other main component, each station is equipped with a continuously operating GPS receiver (cGPS) providing $1 \mathrm{~Hz}$ sampling. The GPS data is uploaded daily to the data processing center at BAKOSURTANAL (Indonesia) or can alternatively be streamed in near real-time to the Warning Center in Jakarta. The GPS receiver (Septentrio PolaRx2) incorporates the high-precision L1/L2 geodetic type with a choke ring antenna and a radome. The GPS monument is built on top of the tide gauge hut or near the tide gauge station; those tide gauge stations are denoted as cGPS@TG. In GITEWS, the GPS is primarily installed to monitor the displacement and the stability of the tide gauge system during earthquakes, but can also be used to correct long-term sea level measurements for vertical land motion.

A meteorological compact sensor (VAISALA WXT510) complements the station equipment and provides basic meteorological observations (e.g., air pressure and temperature, relative humidity, wind speed and direction, rain intensity, duration and accumulation) every minute. The air pressure data is used to separate inverse barometric changes from other effects (e.g., tsunamis) and to support the GPS analysis.

To assure continuous power supply, the station is equipped with a power module that controls the charging of the batteries from different power lines (solar cells and/or mains power) and offers complete digital control over the power input and output. A data control unit comprises the lowvoltage embedded PC104 computer and the battery manager, to which all sensors and the data logger are connected to. The battery manager regulates the power supply of all hardware components and enables or disables the components automatically, depending on pre-configured voltage thresholds. The computer runs different software components for data sampling, data storage and communication functions for the data transmission to the Warning Center in Jakarta.

One of the advantages of the station's computer system is its ability to carry out real-time tide gauge analysis. Tide gauge analysis software with a specially developed trigger algorithm (Sect. 3.1) may detect tsunamis or other sudden changes in the sea level in near real-time. In this case, the station turns itself into "tsunami reporting mode" and starts high-rate data sampling and real-time data transmission. The tsunami reporting mode can either be started internally by the station itself or externally by the Warning Center in Jakarta.

\subsection{Communication}

Strict requirements exist for the communication with tide gauges in tsunami warning systems (Holgate et al., 2008). Selected communication lines must have a short latency, redundancy and they should be independent of any groundbased network, like radio links, mobile phones or the Global 
System for Mobile Communications (GSM). In addition, satellite communication should be insensitive to antenna disalignment by having a large antenna aperture. The GITEWS tide gauges use three different communication systems for redundancy and to fulfill these requirements.

Data for international users and other tsunami warning centers is provided through the GTS system (EUMETSAT, 2009). The sea level readings are re-sampled every minute from its original $20 \mathrm{~s}$ sampling and are transmitted every 15 min with a time lag of one minute. This data stream is retransmitted via EUMETCast. Data of all stations is collected and displayed at the IOC Sea Level Station Monitoring Facility at the Flanders Marine Institute (VLIZ) in Oostende (Belgium) (http://www.ioc-sealevelmonitoring.org) and the University of Hawaii Sea Level Center (UHSLC) (http://uhslc. soest.hawaii.edu).

In addition, all stations are equipped with Inmarsat's Broad Band Global Area Network (BGAN) system (Inmarsat Global Limited, 2009). BGAN provides a simple communication line between the individual stations and the Warning Center in Jakarta. The available bandwidth is about $110 \mathrm{kbps}$ or more. Tide gauge data as well as high-rate GPS data can be transmitted to the Warning Center in very short time with low latency.

A secondary geostationary satellite-based data transmission service is used as a backup. Inmarsat provides a 2.4kbps data service, based on satellite infrastructure and satellite modems of the former Indonesian ACeS system provider (http://www.acesinternational.com).

\subsection{GPS analysis for earthquake events}

There is a clear evidence for rapid co-seismic height changes of the surrounding land during strong and tsunamigenic earthquakes in Sumatra/Indonesia (e.g., Tanioka et al., 2006). These height changes cause variations in the local sea level a few minutes after an earthquake occurs, which may mask or overlap any tsunami-related sea level change. Therefore, all GITEWS tide gauges in Indonesia are equipped with highprecision continuous GPS. The GPS data is sampled at $1 \mathrm{~Hz}$ and stored at the tide gauge site. Under normal conditions, $30 \mathrm{~s}$ sub-sampled data is transmitted on a daily basis for scientific analyses (Sect. 2.4). In the case of a tsunami alert or a strong earthquake, the most recent high-rate backlog GPS data is transmitted to the Warning Center in Jakarta and continuously updated thereafter. For each earthquake-affected station, the vertical displacement to the pre-earthquake situation is computed using Bernese GPS processing software (Dach et al., 2007), as a part of the support functions of the Tsunami Warning Center in Jakarta (Lauterjung et al., 2010). The result is merged with the sea level data from the tide gauge station (Fleischer et al., 2010). The computed vertical displacement is used as an acceptance/rejection criterion for the sea level record of the particular tide gauge station in order to assist the decision process and avoid false tsunami detections (Behrens et al., 2010) at the Warning Center in Jakarta. In cases of vertical displacements of a coastal region during an earthquake, the sea level in this region will slowly adapt to a new level. Because it is difficult to model how the sea level adapts for a certain vertical displacement, the information from a tide gauge is rejected for displacements larger than $10 \mathrm{~cm}$. In addition, the $1 \mathrm{~Hz}$ GPS data can be used to estimate, e.g., the temporal-spatial distribution of the slip during an earthquake (e.g., Larson, 2008; Babeyko et al., 2010), but this technique is not yet used in GITEWS.

The GITEWS tide gauge stations have experienced several strong earthquakes since their installation. However, none of these earthquakes have caused significant vertical displacements (Figs. 3 and 4).

\subsection{GPS analysis for GITEWS tide gauges for scientific use}

Processing and reprocessing of global GPS network data, including stations at tide gauges (cGPS@TGs), has become a standard in Geodesy (e.g., Steigenberger et al., 2006; Wöppelmann et al., 2007; Schöne et al., 2009). GPS data is routinely analyzed at BAKOSURTANAL in a scientific post-processing to gain insight into the tectonic settings of the subduction zone close to Sumatra and Java. GPS phase observations have been analyzed from seven GITEWS tide gauge stations together with GPS data from the International GNSS Service (IGS) global stations (Dow et al., 2009) with a consistent processing strategy over the period from 2008 to 2010 using GAMIT software version 10.35 (Herring et al., 2009).

The processing strategy incorporates up-to-date correction models, including the IERS2003 solid Earth tide model (McCarthy and Petit, 2004), the precession/nutation model IAU2000, the ocean tide loading (Scherneck and Bos, 2001) using the FES2004 tidal model, the absolute satellite and antenna phase center variation offsets (igs05_atx) and the troposphere Global Mapping Function (GMF) with the Global Pressure Temperature (GPT) model. An elevation cutoff angle of $10^{\circ}$ is used in all solutions and the sampling rate data interval is decimated to $120 \mathrm{~s}$.

The GPS analysis estimates daily site coordinates, satellite state vectors, tropospheric zenith delay parameters, Earth orientation parameters and phase ambiguities. Loosely constrained daily solutions were computed using a priori information for site coordinates in the ITRF2005 reference frame (Altamimi et al., 2007), the final orbits from the IGS and the Earth Orientation Parameters (EOPs) from the IERS Bulletin $B$. Then, the daily solutions were combined by using the Global Kalman filter software GLOBK (Herring et al., 2009). The result is a loosely constrained position time series per station for the entire period. To obtain station coordinates in the ITRF2005 an adjustment has been performed using the GLORG software which is part of GLOBK, constraining the ITRF2005 reference frame coordinates and velocities of 
M7.2 Earthquake 09-MAY-2010 near Northern Sumatra, Indonesia

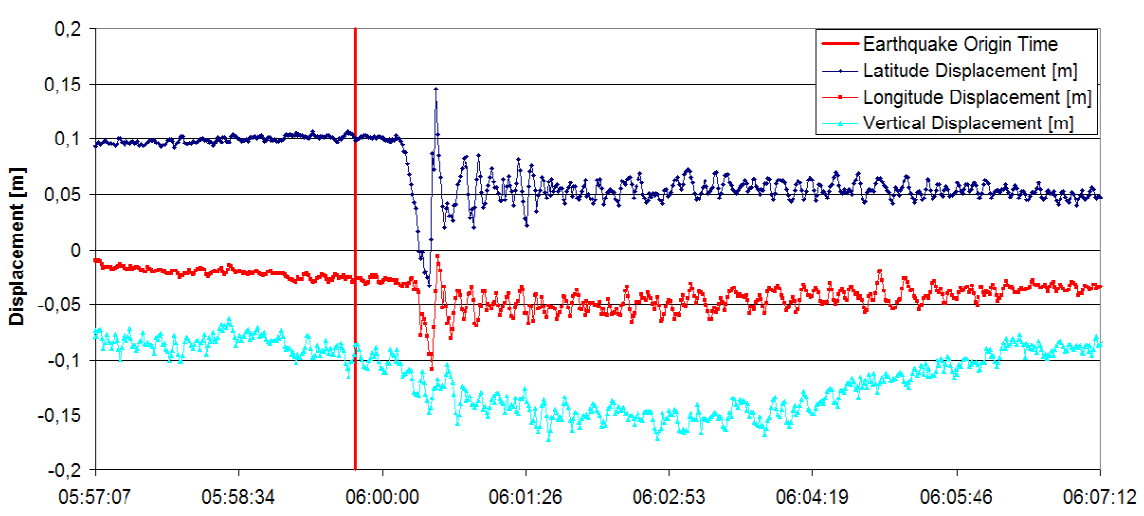

Fig. 3. Displacement of the Meulaboh Tide Gauge during the nearby $M 7.2$ earthquake. The high-frequency ground shaking caused by the earthquake is clearly visible in the horizontal components. Also the displacement in latitude and longitude is easily extractable. Processing was done with TRACK, part of GAMIT/GLOBK.

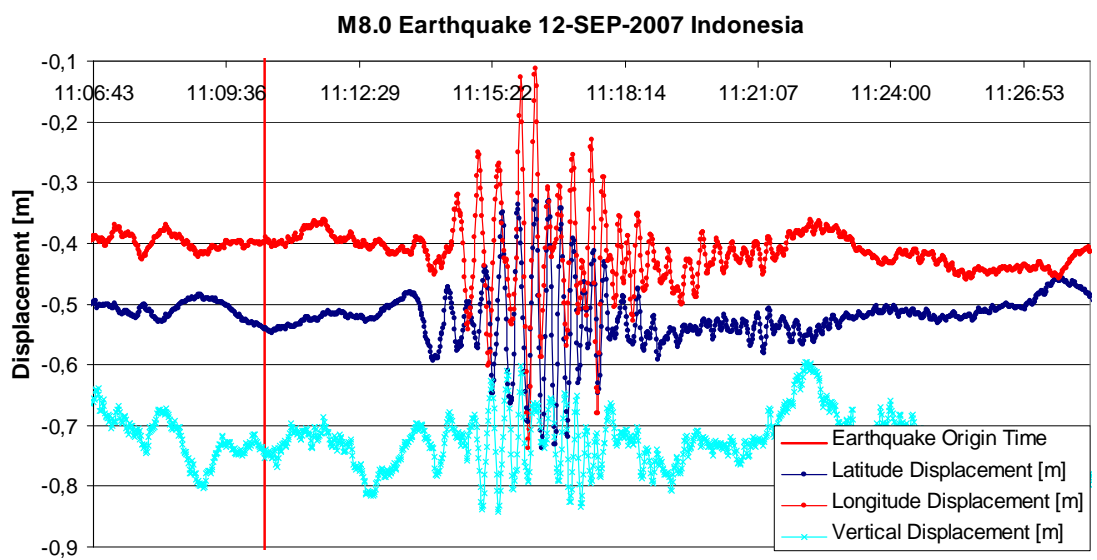

Fig. 4. High-frequency displacement at Telukdalam (Nias Island, Sumatra/Indonesia) due to the M8.0 earthquake near Bengkulu on 12 September 2007. Here, not only a ground shaking in the horizontal can be seen, but also significant vertical ground shaking but no site displacement. This vertical shaking of $20 \mathrm{~cm}$ peak-to-peak, however, is not mapped to the tide gauge record.

appropriate global tracking sites that comprise the reference frame network. The GPS baseline solutions provide geodetic positions with a precision up to a few millimeters. Studies were carried out to evaluate the best strategy to implement new models, including the troposphere GMF mapping function with the GPT model (Boehm et al., 2006); and the results were encouraging. Figure 5 shows that the estimation of geodetic position time series achieves an accuracy level of millimeters for the horizontal and vertical components of coordinates. The GGMatlab software (Herring, 2003) was used for de-trending the geodetic position time series.

The analysis of seven GITEWS cGPS@TG (Fig. 5a) stations, represented by the sites Waikelo (WAIK), Sadeng (SADE), Tanjung Lesung (TJLS), Enggano (GANO), Meulaboh (MEUL), Seblat (SEBL, Fig. 5c), and Telukdalam (TDAL, Fig. 5b) with different types of monument constructions, shows that the repeatability of the geodetic station co- ordinates is $\sim 2 \mathrm{~mm}$ in the North and East component and $\sim 6 \mathrm{~mm}$ in the Up component. With this achieved repeatability, the cGPS@TG network provides the basis to evaluate the current tectonic situation and for the analysis of site displacements caused by larger earthquakes (e.g., the Padang earthquake of 30 September 2009; Fig. 5b and 5c).

\section{Using tide gauges in the tsunami warning chain}

Reliable tsunami warnings require adequate observation of sea level from tide gauge stations and in particular de-trended tide gauge records and tsunami arrival times. Based on the different tide gauge system installations in Indonesia, two approaches are used to analyze tide gauge data and provide tsunami-related parameters. For tide gauges described in Sect. 2, the tidal values are analyzed on-site in real-time and the information is then transmitted. For other tide gauges 


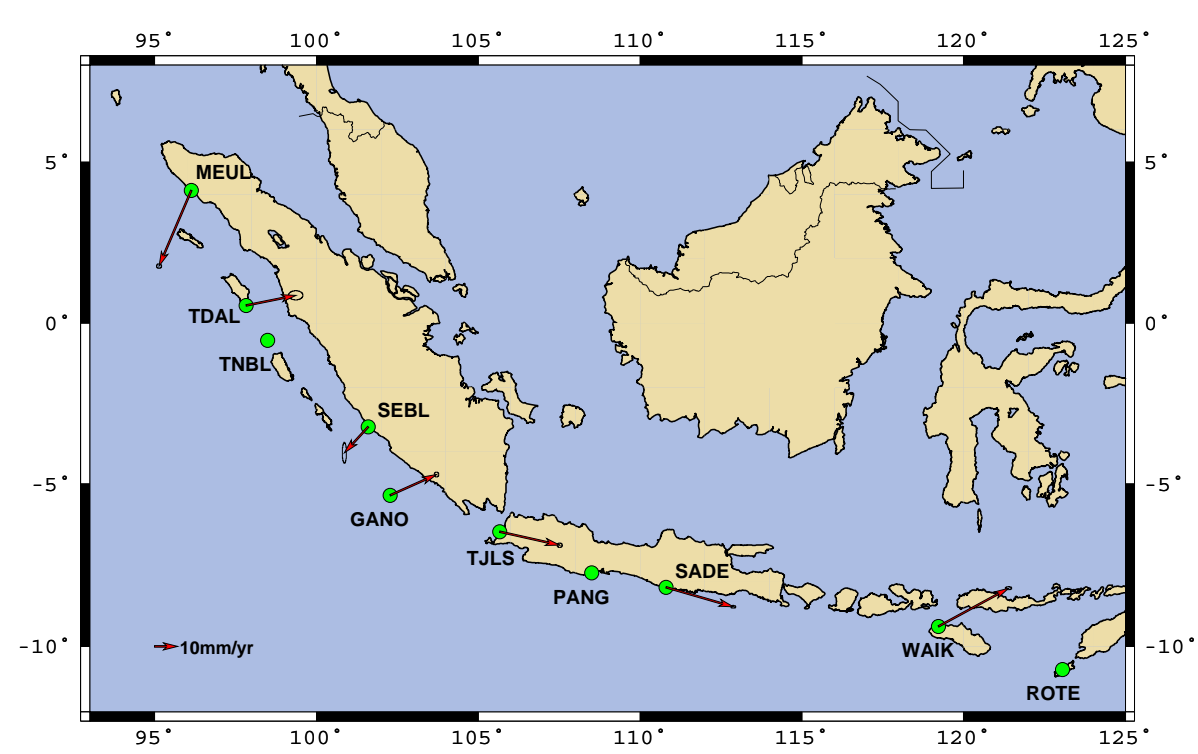

Fig. 5a. Station distribution of GITEWS cGPS@TG sites in Sumatra and Java (Indonesia) including the computed displacement (red arrows) in ITRF2005 for the period from 2008 to 2010. The 2008 to 2010 velocities for sites at Sumatra are dominated by post-seismic displacements (e.g., 26 December 2004, 28 March 2005, and 12 September 2007) and do not reflect plate tectonic settings. Sites east of the Sunda Strait have experienced less severe earthquakes and therefore, closer agreement with the ITRF velocity field. GPS results are not available for ROTE and TNBL.

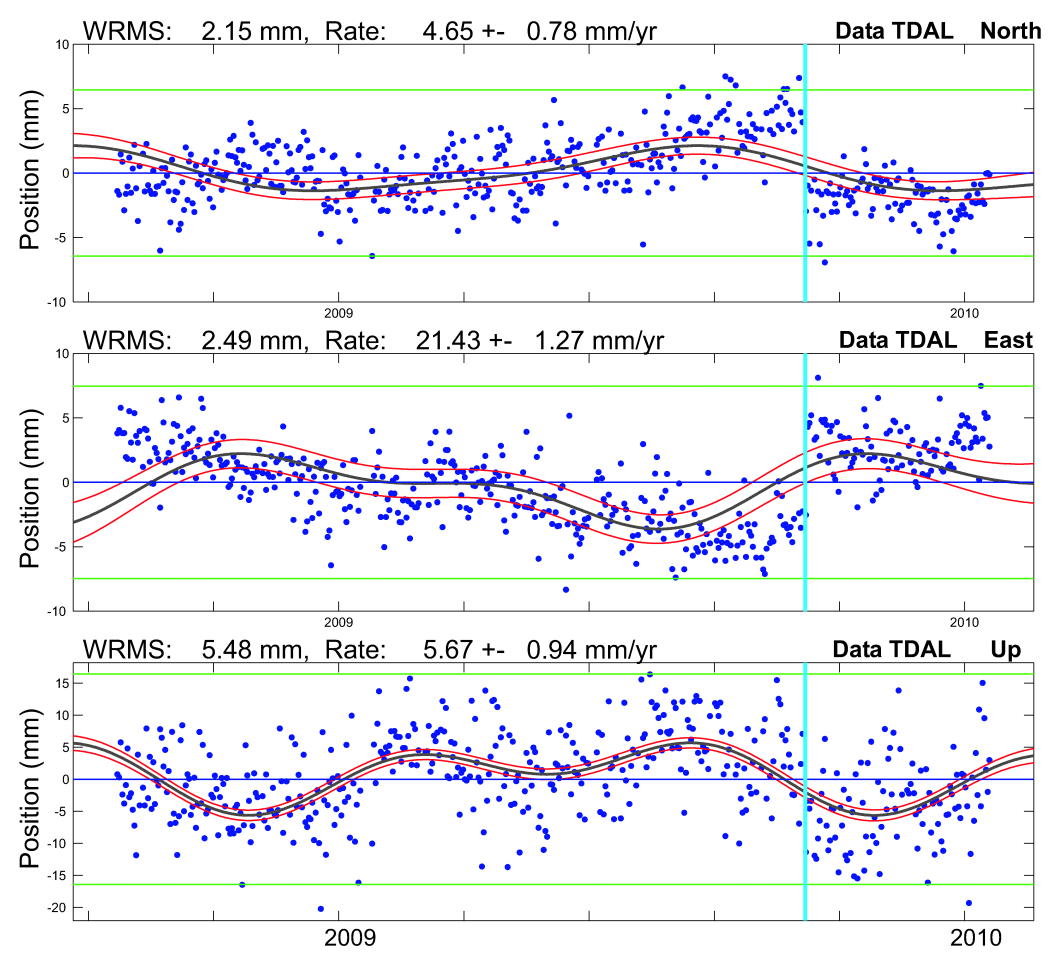

Fig. 5b. cGPS@TG (North, East, Up) at Telukdalam (TDAL), coordinates time series change due to co-seismic displacement of the 30 September 2009 Padang earthquake (light blue line). The graph shows the daily estimates of station coordinates (blue dots), the $3 \sigma$ of the station coordinates (green line), the estimated annual/bi-annual signal (black line) with the $1 \sigma$ (red lines). 

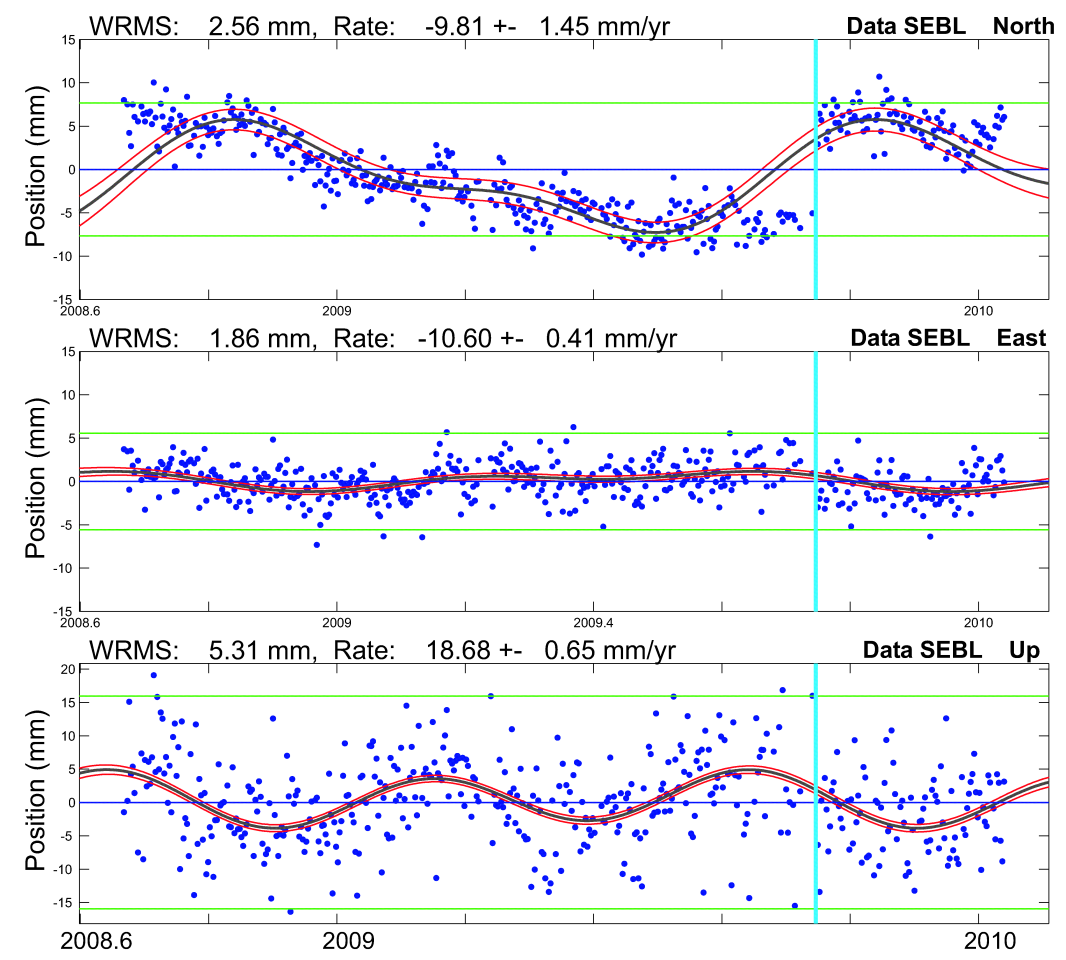

Fig. 5c. cGPS@TG (North, East, Up) at Seblat (SEBL), coordinates time series change due to post-seismic displacements following the October 2007, Bengkulu earthquakes, and 30 September 2009 Padang earthquake (light blue line). Subsidence of the station is relatively high with $\sim 2 \mathrm{~cm} \mathrm{year}^{-1}$. The graph shows the daily estimates of station coordinates (blue dots), the $3 \sigma$ of the station coordinates (green line), the estimated annual/bi-annual signal (black line) with the $1 \sigma$ (red lines).

(operated by BAKOSURTANAL or available from other operators at the IOC Sea Level Station Monitoring Facility), the Warning Center in Jakarta can analyze the data using the same algorithm which is running at the GITEWS tide gauge stations. The algorithm to detect tsunamis or other rapid sea level changes (sea level events, SLE) is described below.

\subsection{The sea level event detection algorithm (SLE)}

The analysis and prediction of tsunami propagation and runup at the coast require de-tided and pressure-corrected sea level time series. In GITEWS, tsunami arrival times and the deviation of the tidal signals from the normal level are used to further constrain the tsunami warning (Behrens et al., 2010). In the past, different approaches were proposed to detect tsunami signals in tide gauge data streams (e.g., Pérez et al., 2009). In GITEWS a detection algorithm has been developed and implemented at the stations (see Chapter 5 in Pérez et al., 2009). In case of a rapid sea level change ("sea level event"/SLE), the software will alert the Warning Center in Jakarta and start to transmit data in near-real time as soon as possible. If an abnormality in the water level is observed, the detection algorithm also triggers the station into a high-rate reporting mode and provides the event time to the Warning Center in Jakarta.
The technical details and formulas of the SLE approach are outlined in Chapter 5 of Pérez et al. (2009). Here only a short description is given. The main part of the SLE detection algorithm predicts the actual sea surface height based on a set of tidal constituents and compares the result with the respective instantaneous measurements of the individual sensors. An earlier tidal analysis for each site is the basis for the prediction of the sea surface heights. Tidal data of up to one year, but not less than 28 days, are analyzed using a least squares approach (Foreman, 1977). The selected tidal constituents for the estimation are primarily based on the local and regional conditions and require user experience.

At first, the data coming from the different tide gauge sensors are analyzed for outages, outliers and the general integrity of the acquired sea level data. For comparison and detiding, a predicted sea level time series is obtained using the set of tidal constituents. Before the de-tiding, the predicted time series is fitted to the actual sea level by computing and applying a moving offset using the past three hours of sea level data. This moving offset accounts for incomplete modeling of tides as well as for local surge effects and long-term changes in mean sea level. The difference between the actual sea level measurement and the fitted prediction is the de-tided time series delivered to the Warning Center. This time series can be further analyzed for tsunami-related signatures. 
One of the main challenges for a sound detection of SLEs is the selection of a suitable threshold for the allowed deviation of the actual sea level from the normal. In the SLE algorithm, this threshold is used for the decision of whether a change in the water level is significant for alerting the Tsunami Warning Center or not. Changes in the sea state conditions, the local harbor conditions, and the individual sampling characteristic of the tide gauge sensors (radar, float or pressure) lead to variable noise levels. This causes a specific, sensor and site-dependent sensitivity of the threshold. Most important is that the algorithm easily adapts to changes in the sea state, since higher sea state conditions will mask small tsunami waves and, therefore, hamper the estimation of the tsunami arrival time. Based on the mathematical variance of the most recent $10 \mathrm{~min}$ of measurements, a sensor- specific noise level is computed. The threshold is then the product of this variance multiplied by a user-defined factor (confidence interval). If the difference between the predicted and measured sea level exceeds the calculated threshold, the value will be internally flagged as a possible sea level event (SLE). To avoid false alarms, the algorithm alerts only when the threshold is consecutively exceeded for a predefined number of times. Henceforward, the Warning Center in Jakarta will receive an "alert message" and the station increases the data transmission to near real-time.

\subsection{Examples of recent tsunamis}

\subsubsection{Tsunami on 2 September 2009, Java Sea}

On 2 September 2009, a M7.4 earthquake occurred in the Java Sea $\left(7.81^{\circ} \mathrm{S} / 107.26^{\circ}\right.$ E, Fig. 6a) (GEOFON, 2009). This earthquake caused a small tsunami (Fig. 6b) which was recorded at the BAKOSURTANAL tide gauge sites of Pameungpeuk $\left(7.66^{\circ} \mathrm{S} / 107.68^{\circ} \mathrm{E}\right)$ and Pelabuhan ratu $\left(6.98^{\circ} \mathrm{S} / 106.54^{\circ} \mathrm{E}\right)$. The BAKOSURTANAL tide gauges report one minute samples. At the time of the event, these tide gauge data was not available at the Warning Center in Jakarta. An analysis of the tide gauge record for Pameungpeuk was carried out and is discussed here. The origin time of the earthquake was 07:55 UTC with an estimated arrival time of the tsunami wave at Pameungpeuk at 08:06 UTC (A. Babeyko, personal communication, 2009). Except for surge effects, the tidal record shows little to no variations in sea level during the earthquake. The SLE counter of the detection algorithm gives almost stable results. On some prior occasions to the tsunami, the actual sea level measurement departs from the predicted value, but none of the events remain for the consecutive samples. At 08:04 UTC the SLE exceeded its pre-defined counter limit for the first time (in this example the SLE counter limit is 3), followed by consecutive samples above the threshold. The tide gauge detection algorithm would have reported an event with an event time of 08:04 UTC to the Warning Center already 2 min later, which fits quite well with forecast of the propagation model and proves the suitability of the detection approach.

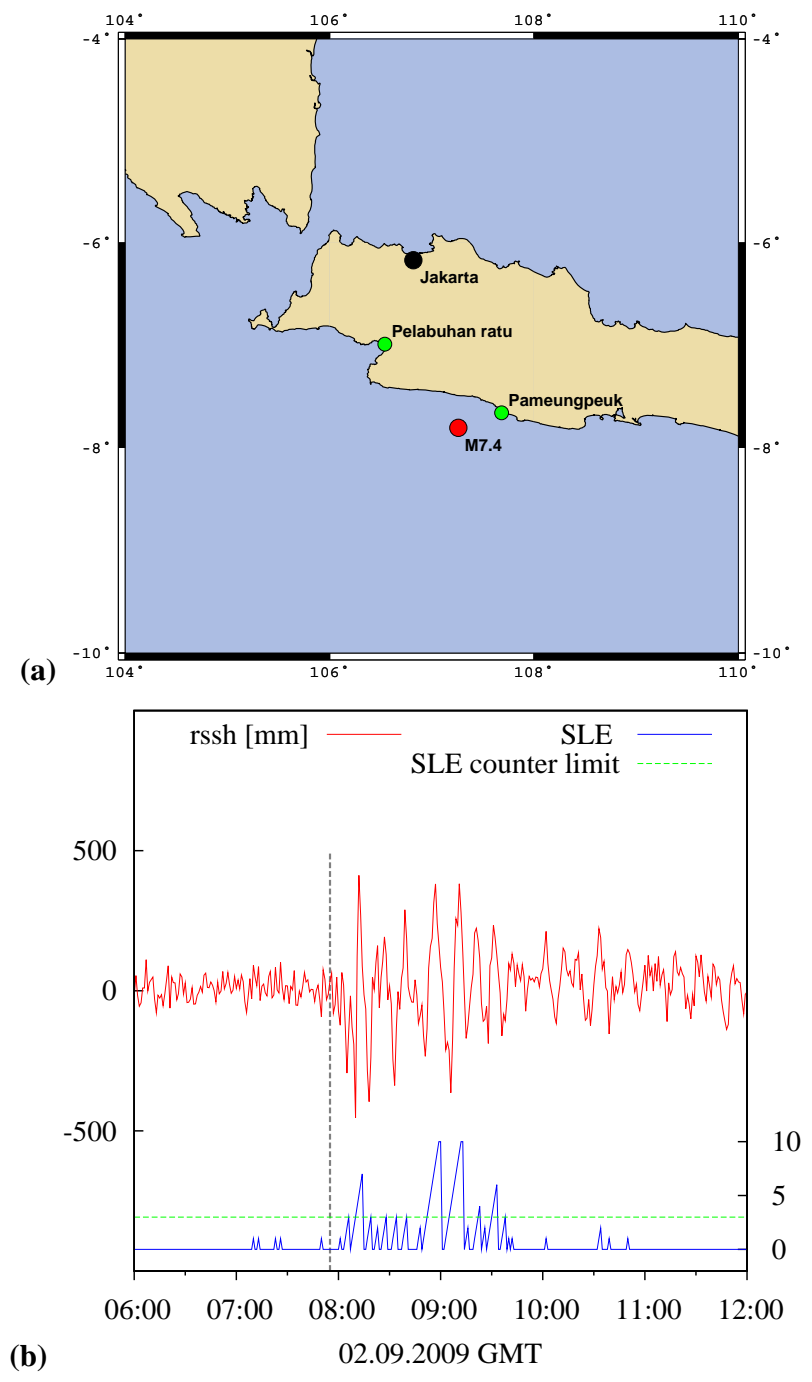

Fig. 6. Location map (a) and sea level curve (b) acquired at Pameungpeuk during the tsunami on 2 September 2009 (GEOFON, 2009). The right hand side graph shows the de-tided sea level curve in mm (left, red), the SLE trigger (value between 1 and 10) (right, blue) and the SLE counter limit (here 3) for tsunami alerting (green). The grey dashed line indicates the earthquake source time.

\subsubsection{Tsunami on 6 April 2010, Northern Sumatra}

The M7.7 (GEOFON, 2010) earthquake on 6 April 2010, 22:15 UTC in Northern Sumatra $\left(2.32^{\circ}\right.$ N/97.12 ${ }^{\circ}$ E) (Fig. 7a) caused a small tsunami, which was recorded at several of the nearby GITEWS tide gauge stations. Here, the sea level record acquired at Meulaboh $\left(4.13^{\circ} \mathrm{N} / 96.13^{\circ} \mathrm{E}\right)$ is discussed. Figure $7 \mathrm{~b}$ shows the de-tided sea level curve and the results of the SLE detection algorithm. This tsunami occurred with a somewhat complex sea state background situation. Around the earthquake origin time, the sea level record is characterized by a high sea state leading to a relatively high threshold of the SLE algorithm. The first detection of a SLE was at 23:35 UTC for the radar gauge. The arrival time did not 


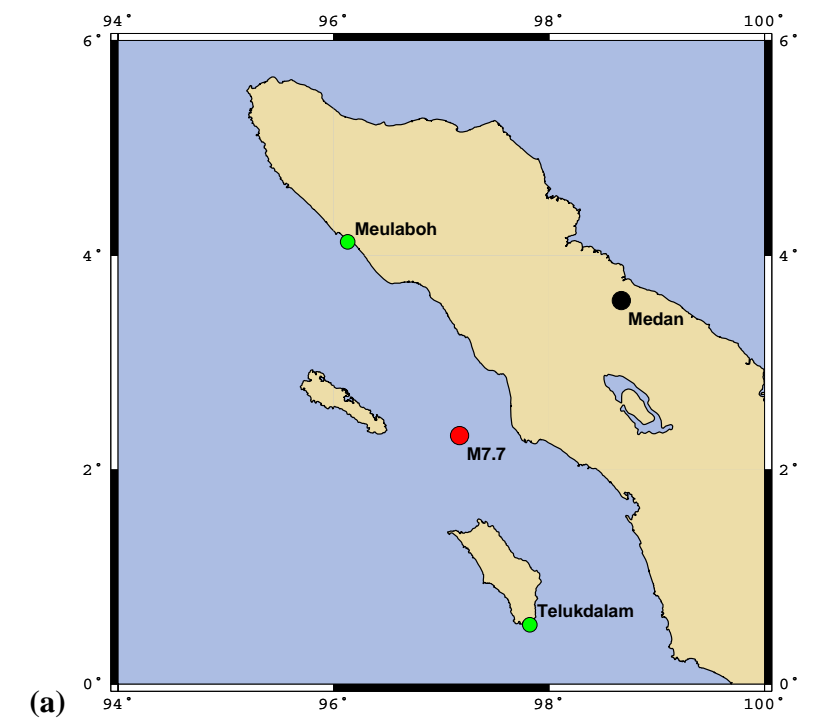

(a)

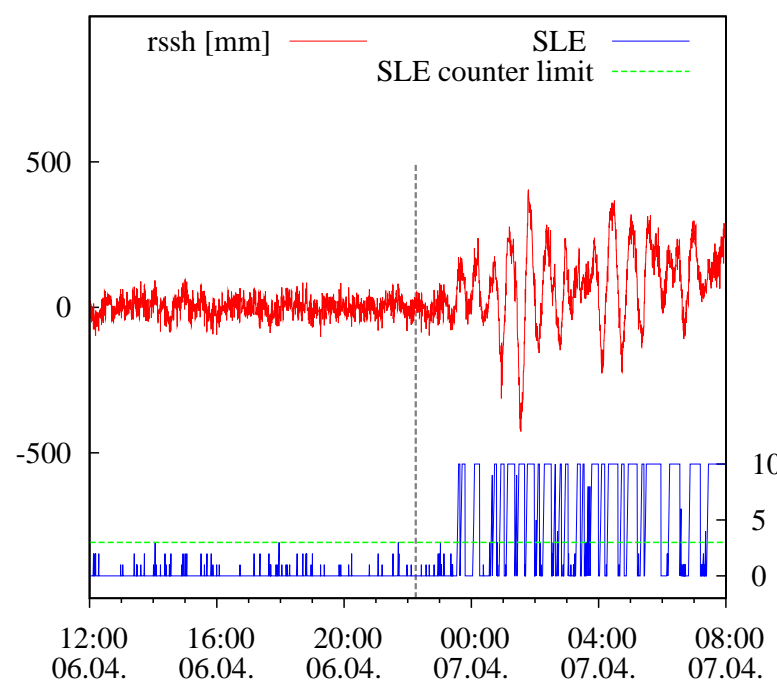

(b)

2010 GMT

\section{Conclusions}

With the installation of GPS-controlled tide gauges in Indonesia, the tsunami warning process is now supported by a high-quality system at selected sites, both for acquiring tide gauge data as well as for estimation of GPS displacements. The GITEWS tide gauge stations have demonstrated excellent performance in data availability and quality of the derived results since their installation. With the newly developed SLE detection algorithm, it is possible to de-tide the tide gauge data and to extract the necessary information to underpin the decision support process in the Warning Center in Jakarta with reliable tsunami arrival times as well as tsunami wave heights.

The examples of recent tsunamis discussed in Sect. 3.2 are two-fold. The results of both events discussed and numerous others not shown here (e.g., Pérez et al., 2009) demonstrate clearly, that the SLE algorithm highly accurately identifies the onset time at which the sea level record indicates a tsunami wave. However, to ensure the correct interpretation of the results of the SLE algorithm with respect to theoretical tsunami propagation models, the individual noise of the time series should be taken into account and the progression of the sea level heights should be used in the matching process (Behrens et al., 2010).

The continuously acquired high-rate GPS data support the local assessment of rapid vertical changes to control the stability of the tide gauge system during and after an earthquake. In addition, the results of the GPS post-processing show that the stations are useful for tectonic studies, even if this was not the original intention.

Acknowledgements. The authors thank their colleagues at GFZ and BAKOSURTANAL for their help in installing, maintaining and operating the tide gauges. In particular the work of Matthias Köppl, Torsten Queisser, Nico Stolarczuk, Christian Selke, Sri Handayani, Joko Ananto, Irpan Septiawan, Erfan Dany Variandy, Sofie Barlianto, Supriadi, Ruddy Sorongan, Amir Machmud, Bayu Triyogo, Tunjung Wismadi, Rustandi Poerawiardi and Yadi Aryadi is gratefully acknowledged here. Also the work and exchange of ideas with Mark Merrifield and his colleagues at the University of Hawaii Sea Level Center as well as Peter Foden, Jeff Pugh and Simon Holgate at Proudman Oceanographic Laboratory (POL, UK) is appreciated. We thank Phil Woodworth (POL) and Thorkild Aarup (UNESCO/IOC) for their reviews and useful comments.

The work has been carried out under the German Ministry of Research and Education grant 03TSU01 and Indonesia's InaTEWS grants 0004.0/083-01.0/-/(2007 till 2010).

This is publication 172 of the GITEWS project (German Indonesian Tsunami Early Warning System).

Edited by: J. Lauterjung

Reviewed by: P. Woodworth and T. Aarup the Warning Center should account for the individual local thresholds. 


\section{References}

Altamimi, Z., Collilieux, X., Legrand, J., Garayt, B., and Boucher, C.: ITRF2005: A new release of the International Terrestrial Reference Frame based on time series of station positions and Earth Orientation Parameters, J. Geophys. Res., 112, B09401, doi:10.1029/2007JB004949, 2007.

Babeyko, A. Y., Hoechner, A., and Sobolev, S. V.: Source modeling and inversion with near real-time GPS: a GITEWS perspective for Indonesia, Nat. Hazards Earth Syst. Sci., 10, 1617-1627, doi:10.5194/nhess-10-1617-2010, 2010.

Behrens, J., Androsov, A., Babeyko, A. Y., Harig, S., Klaschka, F., and Mentrup, L.: A new multi-sensor approach to simulation assisted tsunami early warning, Nat. Hazards Earth Syst. Sci., 10, 1085-1100, doi:10.5194/nhess-10-1085-2010, 2010.

Boehm, J., Werl, B., and Schuh, H.: Troposphere mapping functions for GPS and very long baseline interferometry from European Centre for Medium-Range Weather forecasts operational analysis data, J. Geophys. Res., 111, B02406, doi:10.1029/2005JB003629, 2006.

Dach, R., Hugentobler, U., Fridez, P., and Meindl, M.: Bernese GPS Software Version 5.0, Astronomical Institute, University of Bern, 2007.

Dow, J. M., Neilan, R. E., and Rizos, C.: The International GNSS Service in a changing landscape of Global Navigation Satellite Systems, J. Geodesy, 83, 191-198, doi:10.1007/s00190-0080300-3, 2009.

EUMETSAT: TD 16 - Meteosat Data Collection and Retransmission Service, available at: http://www.eumetsat.int/idcplg?

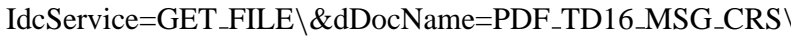
\&RevisionSelectionMethod=LatestReleased, 2009.

Fleischer, J., Häner, R., Herrnkind, S., Kloth, A., Kriegel, U., Schwarting, H., and Wächter, J.: An integration platform for heterogeneous sensor systems in GITEWS - Tsunami Service Bus, Nat. Hazards Earth Syst. Sci., 10, 1239-1252, doi:10.5194/nhess-10-1239-2010, 2010.

Foreman, M. G. G.: Manual for tidal heights analysis and prediction, Institute of Ocean Sciences, Patricia Bay, Pacific Marine Science Rep. 77-10, 66 pp., 1977.

GEOFON, http://geofon.gfz-potsdam.de/db/eqpage.php?id= gfz2009recy, 2009.

GEOFON, http://geofon.gfz-potsdam.de/db/eqpage.php?id= gfz2010gtdx, 2010.

Herring, T. A.: MATLAB Tools for viewing GPS velocities and time series, GPS Solut., 7(3), 194-199, doi:10.1007/s10291-0030068-0, 2003.

Herring, T. A., King, R. W., and McClusky, S. C.: Documentation for the GAMIT/GLOBK GPS processing software release 10.3, Mass. Inst. of Technol., Cambridge, USA, 2009.

Holgate, S., Foden, P., Pugh, J., and Woodworth, P.: Real time sea level data transmission from tide gauges for tsunami monitoring and long term sea level rise observations, Journal of Operational Oceanography, 1, 3-8, 2008.

Inmarsat Global Limited: http://www.inmarsat.com/Downloads/ English/BGAN/Collateral/bgan_overview_brochure_EN.pdf? language $=$ EN\&textonly $=$ False, 2009.
Larson, K. M.: GPS seismology, J. Geodesy, 83, 227-233, doi:10.1007/s00190-008-0233-x, 2008.

Lauterjung, J., Münch, U., and Rudloff, A.: The challenge of installing a tsunami early warning system in the vicinity of the Sunda Arc, Indonesia, Nat. Hazards Earth Syst. Sci., 10, 641646, doi:10.5194/nhess-10-641-2010, 2010.

Manurung, P.: Indonesian Real Time Coastal Sea Level Observing Network. BAKOSURTANAL, in: Workshop on Realtime Transmission and Processing Techniques: Improving the GLOSS Contribution to Multi-Hazard Warning Systems, UNESCO Paris, 2007.

McCarthy, D. D. and Petit, G. (Eds.): IERS conventions (2003), IERS Tech. Note 32, Verl. des Bundesamtes für Kartographie und Geodäsie, Frankfurt am Main, Germany, 2004.

Merrifield, M., Aarup, T., Allen, A., Aman, A., Caldwell, P., Bradshaw, E., Fernandes, R. M. S., Hayashibara, H., Hernandez, F., Kilonsky, B., Martin Miguez, B., Mitchum, G., Pérez Gómez, B., Rickards, L., Rosen, D., Schöne, T., Szabados, M., Testut, L., Woodworth, P. L., Wöppelmann, G., and Zavala, J.: The Global Sea Level Observing System (GLOSS), in: Proceedings of OceanObs'09: Sustained Ocean Observations and Information for Society (Vol. 2), Venice, Italy, 21-25 September 2009, edited by: Harrison, D. E. and Stammer, D., ESA Publication WPP-306, 2009.

Pérez, B., Vela, J., Woodworth, P. L., Wijeratne, E. M. S., Tinti, S., Bressan, L., Schöne, T., and Illigner, J.: Software for Automatic Detection, Analysis and Quality Control of high-frequency and low-latency sea level signals, EU TRANSFER project, Deliverable 4.3.4, Project no. 037058 (GOCE), available at: http: //www.transferproject.eu/, 2009.

Rudloff, A., Lauterjung, J., Münch, U., and Tinti, S.: Preface "The GITEWS Project (German-Indonesian Tsunami Early Warning System)”, Nat. Hazards Earth Syst. Sci., 9, 1381-1382, doi:10.5194/nhess-9-1381-2009, 2009.

Scherneck, H.-G. and Bos, M. S.: An automated internet service for ocean tidal loading calculations, available at: http://www.oso. chalmers.se/ $\sim$ loading, 2001.

Schöne, T., Schön, N., and Thaller, D.: IGS Tide Gauge Benchmark Monitoring Pilot Project (TIGA) - Scientific Benefits, J. Geodesy, 83(3-4), 249-261, doi:10.1007/s00190-008-0269-y, 2009.

Steigenberger, P., Rothacher, M., Dietrich, R., Fritsche, M., Rülke, A., and Vey, S.: Reprocessing of a global GPS network, J. Geophys. Res., 111, B05402, doi:10.1029/2005JB003747, 2006.

Tanioka, Y., Yudhicara, T. Kususose, T., Kathiroli, S., Nishimura, Y., Iwasaki, S.-I., and Satake, K.: Rupture process of the 2004 great Sumatra-Andaman earthquake estimated from tsunami waveforms, Earth Planets Space, 58, 203-209, 2006.

UNESCO: Manual on Sea-level Measurements and Interpretation, Volume IV: An update to 2006, in: IOC Manuals and Guides No. 14, Intergovernmental Oceanographic Commission of UNESCO, Paris, France, JCOMM Technical Report No. 31, WMO/TD. No. 1339, 2006.

Wöppelmann, G., Martin Miguez, B., Bouin, M. N., and Altamimi, Z.: Geocentric sea-level trend estimates from GPS analyses at relevant tide gauges world-wide, Global Planet. Change, 57(34), 396-406, 2007. 